\title{
PENGEMBANGAN VARIASI LATIHAN TEKNIK DASAR RENANG GAYA BEBAS DAN GAYA DADA MELALUI VIDEO COMPACT DISK PADA KEGIATAN EKSTRAKURIKULER RENANG DI SMP NEGERI 8 MALANG
}

\author{
Mohammad Syamsul Anam \\ Tatok Sugiarto \\ Usman Wahyudi \\ Fakultas IImu Keolahragaan Universitas Negeri Malang \\ Email: Syamsulanam42@gmail.com
}

\begin{abstract}
This research and development intended to develop basic technique exercise variation on front crawl and breast stroke swimming through compact disk video in swimming extracurricular activity at State Junior High School 8 Malang. This research and development used developing research method of Borg \& Gall research and development, with research subjects 40 participants extracurricular activities pool. The procedures performed include: requirements analysis, product development and product trials. Products produced in the form of variations in practice the basic techniques of front craw and breaststroke with a conclusion: (1) Variation practice basic techniques of frort craw very valid means can be used, (2) Variations in practice the basic techniques of swimming the breaststroke very valid means can be used, (3) Variations in basic engineering practice freestyle and breaststroke is very attractive, easy to understand, easy to do and very beneficial.
\end{abstract}

Keywords: Exercise Variation, Swimming Basic Technique, Front Crawl, Breast Stroke, Extracurricular, VCD

\begin{abstract}
Abstrak: Penelitian ini dilaksanakan dengan tujuan untuk mengembangkan variasi latihan teknik dasar renang gaya bebas dan gaya dada melalui video compat disk pada kegiatan ekstrakurikuler renang di SMP Negeri 8 Malang. Penelitian ini menggunakan metode penelitian dan pengembangan research and development Borg dan Gall, dengan subjek penelitian 40 peserta kegiatan ekstrakurikuler renang. Prosedur yang dilakukan berupa: analisis kebutuhan, pengembangan produk dan uji coba produk. Produk yang dihasilkan berupa variasi latihan teknik dasar renang gaya bebas dan gaya dada dengan kesimpulan: (1) Variasi latihan teknik dasar renang gaya bebas sangat valid artinya dapat digunakan, (2) Variasi latihan teknik dasar renang gaya dada sangat valid artinya dapat digunakan, (3) Variasi latihan teknik dasar renang gaya bebas dan gaya dada ini sangat menarik, mudah dipahami, mudah dilakukan dan sangat bermanfaat.
\end{abstract}

Kata Kunci: Variasi Latihan, Teknik Dasar Renang, Gaya Bebas, Gaya Dada, Ekstrakurikuler, VCD

Belajar olahraga renang di era globalisasi adalah sebuah tuntutan untuk mengikuti perkembangan jaman dalam membentuk sumber daya manusia (SDM) yang unggul dan mampu bersaing. Renang merupakan salah satu cabang olahraga yang populer di Indonesia, pembinaan yang dilakukan terhadap olahraga renang pada saat ini sedang giat - giatnya diupayakan, baik pembinaan yang menyangkut prestasi atlet maupun sebagai olahraga pendidikan disekolah sebagai realisasi dari pengajaran pendidikan jasmani dan kesehatan.

Pelaksanaan olahraga renang sebaiknya diterapkan dengan sebaik mungkin, karena renang selain sebagai olahraga 
Mohammad Syamsul Anam, Pengembangkan Variasi Latihan Teknik Dasar Renang Gaya Bebas Dan Gaya Dada Melalui Video Compact Disk Pada Kegiatan Ekstrakurikuler Renang Di SMP Negeri 8 Malang

membentuk fisik juga mampu menjadi sarana refresing bagi peserta yang seharian jenuh belajar didalam kelas. Olahraga renang pada umumnya dilakukan di kolam renang, tetapi banyak juga anak pedesaan menjadikan sungai sebagai prasarana dalam belajar berenang ataupun hanya sekedar bermain air. Menurut Supriyanto \& Lismadiana (2013:113) olahraga renang merupakan aktivitas yang dilakukan di air dengan berbagai macam bentuk dan gaya yang sudah sejak lama dikenal banyak memberikan manfaat kepada manusia. Renang adalah olahraga yang dilakukan di dalam air, dengan menggerakan anggota badan dengan mengapung di air dan seluruh anggota badan yang lain begerak bebas di air dan biasanya tanpa perlengkapan buatan. Berenang bisa menjadi kegiatan rekreasi dan olahraga (Roeswan \& Soekarno, 1979:23). Menurut Haller (2007:8) menyatakan berenang bukan saja merupakan olahraga, tetapi juga merupakan sarana untuk mengisi waktu senggang. Bedasarkan penjelasan di atas dapat disimpulkan renang adalah sesuatu kegiatan yang dilakukan di air dengan menggerakkan seluruh anggota badan untuk mengapungkan badan yang tujuannya untuk berpindah ke satu tempat ketempat yang lain dan olahraga renang juga dapat menjadi sarana kegiatan rekreasi. Bahkan pada jaman dahulu renang sering dipergunakan untuk membela diri dari serangan musuh, dan juga sebagai kemampuan untuk mencari makanan (ikan).

Setiap olahraga pasti memiliki ciri khas yang berbeda-beda, pada olahraga renang sendiri memiliki empat gaya dan masing masing gaya memiliki tingkat kesulitan berbeda-beda. Secara umum ada empat macam gaya dalam olahraga renang yaitu gaya dada (breast stroke), gaya bebas (the crawl stroke), gaya kupu-kupu (butterfly stroke), dan gaya punggung (back crawl) (Haller, 2007:16). Dari keempat gaya tersebut gaya dada dan gaya bebas sering diajarkan ditingkat SMP maupun kegiatan ekstrakurikuler karena mudah untuk di pelajari.

Gaya bebas adalah gaya renang yang paling cepat dan efisien. Cocok sebagai permulaan karena mudah dilakukan seperti gaya renang anjing yang biasa digunakan anak saat pertama kali berenang, serta merupakan gaya paling alami untuk diajarkan dan dipelajari (Meredith, 2006: 50). Sewaktu mengambil napas pada gaya bebas, perenang bisa memilih untuk menoleh ke kiri atau ke kanan. Dengan gerakan ini, tidak banyak anggota tubuh yang menghambat sehingga membuat laju renang semakin cepat.

Gaya dada merupakan gaya renang yang paling mudah karena gerakannya menyerupai katak, oleh karena itu orang sering menyebutnya dengan gaya katak (Nawangsari, 2009:21). Gaya ini pula yang dahulu digunakan Kapten Webb ketika menyebrangi Selat Inggris dan masih digolongkan sebagai gaya yang paling efektif untuk jarak jauh hingga sekarang (Haller, 2007:16).

Materi renang gaya bebas dan gaya dada di tingkat SMP idealnya diajarkan melalui kegiatan intrakurikuler sekolah, tetapi hal tersebut terbentur dengan masalah waktu dan sarana prasarana, mengakibatkan materi tersebut tidak bisa diajarkan secara maksimal dan menyeluruh, sehingga dibentuk suatu kegiatan ekstrakurikuler renang, harapannya dapat mengembangkan potensi bakat dan minat yang dimiliki oleh peserta kegiatan ekstrakurikuler.

Kegiatan ekstrakurikuler di jelaskan dalam Permendikbud (2013) kegiatan pendidikan yang dilakukan oleh peserta didik di luar jam belajar kurikulum standar sebagai perluasan dari kegiatan kurikulum dan dilakukan di bawah bimbingan sekolah dengan tujuan untuk mengembangkan kepribadian, bakat, minat, dan kemampuan peserta didik yang lebih luas atau di luar minat yang dikembangkan oleh kurikulum. Pasal 3 Undang-Undang Nomor 20 Tahun 2003 tentang Sistem Pendidikan Nasional menyebutkan bahwa: Pendidikan nasional bertujuan untuk mengembangkan potensi peserta didik agar menjadi manusia yang: beriman dan bertakwa kepada Tuhan Yang Maha Esa, berakhlak mulia, sehat, berilmu, cakap, kreatif, mandiri, dan menjadi warga negara yang demokratis serta bertanggung jawab.

Menurut Mulyono (2008:187) ekstrakurikuler adalah kegiatan pelajaran yang di selenggarakan di luar jam pelajaran biasa yang dimaksudkan mengembangkan salah satu bidang pelajaran yang diminati oleh sekelompok siswa misalnya olahraga, kese- 
nian, dan berbagai kegiatan keterampilan dan kepramukaan. Menurut Kompri (2014 :224) kata ekstrakurikuler memiliki arti kegiatan tambahan di luar rencaa pelajaran atau pendidikan tambahan diluar kurikulum. Dengan demikian, kegiatan ekstrakurikuler merupakan kegiatan yang dilakukan di luar kelas dan di luar jam pelajaran (kurikulum) untuk menumbuh kembangkan potensi sumber daya manusia yang dimiliki peserta didik. Maka dapat disimpulkan ekstrakurikuler adalah sebuah kegiatan yang dilakukan di luar jam pelajaran (intrakurikuler) dengan tujuan mengembangkan kemampuan peserta didik dalam hal, berkomunikasi, bekerja sama dengan orang lain, serta menemukan dan mengembangkan potensinya (keterampilan).

Melalui penambahan jam pada kegiatan tersebut, maka materi renang gaya bebas dan gaya dada dapat tersampaikan dengan baik dan maksimal, dengan demikian hasil kegiatan tersebut mampu meningkatkan hasil belajar peserta pada kegiatan intrakurikuler. Akan tetapi pada kenyataanya masih sering dijumpai masalah - masalah pada kegiatan ekstrakurikuler di SMP Negeri 8 Malang, yang menbuat kegiatan tersebut kurang berjalan lancar dan mengurangi tujuan dibentuknya suatu kegiatan ekstrakurikuler renang. Berikut hasil pengumpulan data awal yang dilakukan oleh peneliti pada kegiatan ekstrakurikuler renang di SMP N 8 Malang.

Hasil observasi yang dilakukan pada tanggal 29 Agustus 2015 di kegiatan ekstrakurikuler renang SMP Negeri 8 Malang ditemukan; (1) materi yang diberikan pelatih adalah renang gaya bebas dan gaya dada, (2) Latihan yang dilakukan adalah latihan teknik dasar renang gaya bebas dan gaya dada, (3) Selama kegiatan latihan peserta hanya diberikan model latihan yang tradisional, seperti latihan menggerakkan kaki dengan cara duduk ditepi kolam, berseluncur tanpa gerakan kaki dan lengan, dan latihan secara berpasangan, (4) Peserta tidak menggunakan alat bantu selama proses latihan berlangsung, contoh : papan seluncur dan alat bantu lainnya,

Hasil penelitian awal yang dilakukan pada tanggal 3 Oktober 2015 melalui penyebaran kuesioner terhadap 30 siswa peserta kegiatan ekstrakurikuler renang
SMP Negeri 8 Malang, diperoleh ; (1) 96,6 $\%$ peserta menyatakan renang gaya bebas dan gaya dada sering di ajarkan oleh pelatih, (2) 12 dari 30 peserta (40\%) menyatakan jarang mendapatkan variasi latihan teknik dasar renang gaya bebas dan gaya dada yang bermacam macam, sedangkan 11 peserta dari $30(36,6 \%)$ menyatakan pernah mendapat variasi latihan teknik dasar renang gaya bebas dan gaya dada bermacam macam, seperti latihan secara berpasangan, menggerakkan kaki sambil duduk di tepi kolam, (3) 25 dari 30 peserta $(83,33 \%)$ menyatakan variasi latihan teknik dasar renang gaya bebas dan dada sangat diperlukan untuk memudahkan dalam belajar berenang, (4) 30 peserta (100\%) menyatakan pelatih tidak pernah menyampaikan sebuah materi renang melalui VCD (Video Compact Disk).

Hasil penyebaran kuesioner terhadap 1 pelatih ekstrakurikuler dan 2 guru (mantan pelatih ekstrakurikuler renang) SMP Negeri 8 Malang, diperoleh ; (1) 2 dari 3 narasumber menyatakan jarang memberikan model variasi latihan renang gaya bebas dan dada yang bermacam macam, variasi yang pernah diberikan seperti latihan secara berpasangan, menggerakkan kaki sambil duduk di tepi kolam, (2) 3 narasumber menyatakan tidak pernah memberikan materi variasi latihan renang gaya bebas dan gaya dada melalui video, (3) 3 narasumber menyatakan variasi latihan teknik dasar renang gaya bebas dan dada sangat diperlukan untuk memudahkan dalam belajar berenang.

Hasil dari analisis kebutuhan yang di paparkan diatas, maka solusi yang ditawarkan adalah pemberian variasi latihan teknik dasar gaya bebas dan gaya dada melalui video compact disk pada kegiatan ekstrakurikuler renang di SMP N 8 Malang. Menurut Lekso (2013:5) latihan adalah proses yang sistematis dari kegiatan berlatih atau bekerja secara berulang-ulang, dengan kian hari - kian bertambah jumlah beban latihan atau pekerjaannya. Menurut Hadisasminta dan Syarifuddin (1996:145), latihan adalah proses yang sistematis dari berlatih yang dilakukan secara berulang-ulang, dengan kian hari - kian menambah jumlah beban latihan serta intensitas latihannya. Menurut Harsono (1988:100) "tujuan serta sasaran utama dari latihan atau trainning 
Mohammad Syamsul Anam, Pengembangkan Variasi Latihan Teknik Dasar Renang Gaya Bebas Dan Gaya Dada Melalui Video Compact Disk Pada Kegiatan Ekstrakurikuler Renang Di SMP Negeri 8 Malang

adalah untuk membantu atlet meningkatkan keterampilan dan prestasinya semaksimal mungkin". Berdasarkan apa yang dikemukakan oleh para ahli dapat disimpulkan latihan adalah kegiatan yang dirancang secara sistematis dan berkelanjutan ditingkatkan secara bertahap dari yang termudah ke bagian yang tersulit, bertujuan untuk menbentuk manusia dari fisiologis dan psikologisnya bahkan untuk mencapai sebuah prestasi olahraga.

Kegiatan latihan yang dilakukan dalam jangka waktu lama harus disampaikan secara bervariasi tujuannya adalah agar latihan tidak tampak monoton, dapat meningkatkan antusias peserta, peserta tidak cepat merasa bosan, bahkan jika latihan dilakukan dengan baik dapat meningkatkan hasil belajar peserta dalam pelajaran pendidikan jasmani dan kesehatan khususnya dalam cabang olahraga renang. Apalagi pada zaman modern seperti ini pelatih dan peserta kegiatan ekstrakurikuler renang dituntut untuk mampu melakukan latihan latihan yang bervariasi. Menurut Budiwanto (2012:18) Dalam upaya mengatasi kebosanan dan latihan yang monoton, diharapkan seorang pelatih kreatif dengan memiliki banyak pengetahuan dan berbagai jenis latihan yang memungkinkan dapat bergantiganti secara periodik.

Sidik, Zafar D menyatakan prinsip variasi latihan sebagai berikut, Kompleksnya latihan dan tingginya tingkat pembebanan dalam latihan untuk sukses membutuhkan variasi bentuk latihan dan metode latihan agar tidak terjadi kejenuhan / kebosanan (boredom) atau basi (staleness). Faktor kebosanan ini akan menjadi kritis apabila kurang bervariasi seperti pada gerakan (hanya) lari saja yang secara teknik tidak begitu kompleks (terbatas) dan membutuhkan faktor fisiologik.

Bedasarkan paparan para ahli dapat disimpulkan latihan yang bervariasi sangat dibutuhkan untuk mencegah kebosanan dan latihan yang monoton pada setiap latihan yang rutin dilakukan, dengan banyak variasi latihan yang dilakukan dapat menghasilkan kemampuan keterampilan gerak yang baik, mental yang tangguh, dan kejiwaan yang baik bagi peserta ekstrakurikuler. Bahkan jika latihan sering menggunakan variasi latihan yang bermacam-macam, akan dapat meningkatkan partisipasi peserta dalam mengikuti suatu kegiatan latihan.

Variasi latihan gaya bebas dan gaya dada yang dikembangkan ini, akan dilakukan di 2 tempat yaitu di darat dan di air. Variasi latihan ini juga menggunakan alat bantu tali karet yang elastis yang digunakan dikedua pergelangan kaki secara diikat dan digunakan pada bagian kedua telapak tangan yang di ikatkan pada tiang. Tujuan dari alat bantu karet yang digunakan dipergelangan kaki dan ditelapak tangan adalah untuk melatih gerakan dasar kaki, tangan baik itu gaya bebas dan gaya dada.

Sekaligus untuk meningkatkan ketertarikan peserta hasil pengembangan ini akan disebarkan melalui sebuah media, melalui media siswa juga lebih mudah menerima sebuah materi, bahkan dalam dunia pendidikan sekarang penelitian pengembangan yang menghasilkan sebuah produk kebanyakan menggunakan media teknologi yang banyak digemari peserta didik (siswa-siswi). Media yang dipiliha yaitu VCD (video compact disk) Selain dapat menarik perhatian siswa, materi yang di kemas dalam bentuk media VCD akan lebih simpel untuk dibawa kemana-mana karena file video variasi latihan dalam VCD ini dapat disimpan di computer atau handphone para peserta.

Menurut Dwiyogo (2010: 229) Media adalah segala bentuk dan saluran yang dapat dipergunakan dalam suatu proses penyajian informasi. Media adalah alat atau cara yang digunakan sebagai perantara untuk menyajikan informasi (pesan) agar dapat diterima oleh penerima informasi sepenuhnya. Menurut Miarso (2007: 458) menyimpulkan "media pembelajaran adalah segala sesuatu yang digunakan untuk menyalurkan pesan serta dapat merangsang pikiran, perasaan, perhatian, dan kemauan si belajar sehingga dapat mendorong terjadinya proses belajar yang disengaja, bertujuan, dan terkendali".

Berdasarkan hasil analisis yang dikemukakan di atas, maka akan dilakukan suatu penelitian dan pengembangan yang berjudul "Pengembangkan Variasi Latihan Teknik Dasar Renang Gaya Bebas Dan Gaya Dada Melalui Video Compact Disk Pada Kegiatan Ekstrakurikuler Renang Di SMP Negeri 8 Malang".

Pada penelitian dan pengembangan ini, peneliti memiliki asumsi yaitu: Asumsi 
Substansive, Asumsi yang berhubungan dengan masalah penelitian dan merupakan simpulan awal dari hasil atau tujuan dari penelitian yang dilakukan. Berikut asumsi substansiv pada penelitian pengembangan variasi latihan teknik dasar renang gaya bebas dan gaya dada, (1) dapat meningkatkan antusias, ketertarikan dan memudahkan peserta dalam belajar renang gaya bebas dan dada, (2) menjadi sumber referensi bagi pelatih dalam memberikan materi latihan, (3) mampu meningkatkan kesempurnaan teknik dasar renang gaya bebas dan dada, (4) peserta akan lebih tertarik dan memperhatihan jika variasi latihan teknik dasar renang gaya bebas dan gaya ini disampaikan memalui VCD. Asumsi Metodologis, asumsi yang berhubungan dengan metodologi penelitian yang digunakan. Asumsi metodologis penelitian ini adalah metode penelitian pengembangan, penelitian pengembangan merupakan metode yang sesuai untuk memecahkan masalah yang ditemukan di kegiatan ekstrakurikuler renang di SMP Negeri 8 Malang.

Produk pengembangan ini memiliki keterbatasan sebagai berikut: (1) Variasi latihan yang di kembangkan hanya teknik dasar gaya bebas dan dada, (2) Variasi latihan ini hanya dilakukan di darat dan di air, (3) Variasi latihan teknik dasar renang gaya bebas dan gaya dada ini hanya di uji cobakan pada kegiatan ekstrakurikuler renang SMP Negeri 8 Malang.

\section{METODE}

Model penelitian dan pengembangan (Research and Development) yang digunakan peneliti berupa model procedural yang merujuk pada penelitian dan pengembangan Borg dan Gall (1979:626) yang diterjemahkan ke dalam bahasa Indonesia, sehingga mempermudah dalam pemahamannya, adapun terjemahannya sebagai berikut. (1) Melakukan penelitian dan pengumpulan informasi (kajian pustaka, pengamatan kelas, persiapan laporan pokok persoalan), (2) Melakukan perencanaan (pendefinisian keterampilan, perumusan tujuan, penentuan urutan pengajaran, dan uji coba skala kecil), (3) Mengembangkan bentuk produk awal (penyiapan materi pengajaran, penyusunan buku pegangan, dan perlengkapan evaluasi), (4) Melakukan uji coba lapangan permulaan (dilakukan pada 2-3 sekolah, penggunaan 6-12 subjek), (5) Melakukan revisi terhadap produk utama (sesuai dengan saran-saran dari hasil uji lapangan permulaan), (6) Melakukan uji lapangan utama (dengan 5-10 sekolah dengan 30-100 subjek), (7) Melakukan revisi produk (berdasarkan dari saran-saran dan hasil uji coba lapangan utama), (8) Uji lapangan meliputi 10-30 sekolah dengan 40400 subjek, (9) Revisi produk akhir, (10) Membuat laporan mengenai produk pada jurnal, bekerja dengan penerbit yang dapat melakukan distribusi secara komersil.

Dari langkah-langkah yang sudah dikemukakan oleh Borg and Gall, peneliti tidak menggunakan keseluruhan langkahlangkah yang dikemukakan oleh Borg and Gall, melainkan hanya mengambil 7 langkah, karena pertimbangan waktu dan biaya yang dimiliki. Metode penelitian tersebut dimodifikasi dengan mengacu pada teori Ardhana (2002:9) yang menjelaskan bahwa pada setiap pengembangan tentu saja dapat memilih dan menentukan langkah-langkah yang paling tepat bagi dirinya berdasarkan kondisi khusus yang dihadapinya pada saat proses pengembangan.

Adapun langkah-langkah yang diambil yaitu sebagai berikut: (1) Melakukan observasi awal dan Penyebaran kuisioner yang dilakukan peneliti pada tanggal 29 Agustus 2015 dan 3 Oktober 2015 di kegiatan ekstrakurikuler renang SMPN 8 Malang. Subyeknya yaitu 30 peserta dan 3 pelatih kegiatan ekstrakurikuler renang, (2) Mengembangkan produk awal berupa variasi latihan teknik dasar renang gaya bebas dan gaya dada yang dikemas dalam bentuk VCD, (3) Uji Coba Produk yaitu Evaluasi 3 ahli dengan kualifikasi 1 ahli praktisi kepelatihan olahraga renang, 1 ahli akademisi kepelatihan olahraga renang dan 1 ahli media, (4) Uji coba kelompok kecil yang dilakukan dengan melibatkan 10 subjek peserta kegiatan ekstrakurikuler SMPN 8 Malang, (5) Revisi produk awal sesuai dengan hasil uji coba kelompok kecil, (6) Uji coba kelompok besar dengan menggunakan 30 subyek peserta kegiatan ekstrakurikuler SMPN 8 Malang, (7) Revisi produk akhir 
Mohammad Syamsul Anam, Pengembangkan Variasi Latihan Teknik Dasar Renang Gaya Bebas Dan Gaya Dada Melalui Video Compact Disk Pada Kegiatan Ekstrakurikuler Renang Di SMP Negeri 8 Malang

sesuai dengan hasil uji coba kelompok besar. Kemudian hasil akhir produk yaitu berupa pengembangan variasi latihan teknik dasar renang gaya bebas dan dada melalui video compact disk pada kegiatan ekstrakurikuler renang di SMP N 8 Malang.

Jenis data pada penelitian ini Penelitian dan pengembangan ini memiliki 2 macam data yang diperoleh, yaitu data kualitatif dan data kuantitatif. Data kualitatif berupa tinjuan dari beberapa ahli dengan rincian yaitu ahli media, ahli praktisi kepelatihan olahraga renang dan ahli akademisi kepelatihan olahraga renang. Data kuantitatif diperoleh dari hasil persentase angket (kuesioner).

Instrumen yang digunakan dalam penelitian dan pengembangan ini meng-gunakan instrumen non tes berupa angket dan wawancara. Kuesioner digunakan untuk memperoleh data pada saat analisis kebutuhan kepada pelatih dan peserta kegiatan ekstrakurikuler, sebagai evaluator dan peserta sebagai subjek uji coba. Dengan kuesioner ini orang dapat diketahui tentang keadaan/data diri, pengalaman, pengetahuan sikap atau pendapatnya, dan lain-lain. Pilihan jawaban yang tercantum dalam angket masing-masing di konversi seperti untuk keperluan analisis data, maka jika memilih jawaban (a) setuju/selalu/sangat setuju diberi skor 4, jawaban (b) raguragu/kadang-kadang/netral diberi skor 3, jawaban (c) tidak setuju/hampir tidak pernah/negatif diberi skor 2, dan jawaban (d) sangat tidak setuju/tidak pernah diberi skor

Teknik analisis data yang digunakan dalam pengembangan variasi latihan teknik dasar renang gaya bebas dan gaya dada melalui video compact disk pada kegiatan ekstrakurikuler renang SMP N 8 Malang adalah teknik analisis data kualitatif dan kuantitatif. Menurut Sugiyono (2013:335) teknik analisis data kualitatif dan kuantitatif adalah: bersifat induktif, yaitu suatu analisis berdasarkan data yang diperoleh, selanjutnya dikembangkan pada hubungan tertentu atau menjadi hipotesis Analisis kualitatif diperoleh dari data wawancara, observasi, dan kuisioner atau angket, selanjutnya data disajikan sampai tahap kesimpulan. Data diperoleh dari ahli media, ahli olahraga renang. Analisis kuantitatif diperoleh dari pengolahan data hasil dari pengisian kuesioner dengan menggunakan rumus dan analisis persentase dari Akbar (2015:82).

$$
V=\frac{T S e}{T S h} \times 100 \%
$$

Ket :

$\mathrm{V}$ : Validitas

TSe : Total Skor Empirik Validator

TSh : Skor maksimal yang diharapkan

100\%: Konstanta

Tabel 1. Analisis Persentase

\begin{tabular}{lll}
\hline $\begin{array}{c}\text { Kriteria Pencapaian } \\
\text { Nilai } \\
\text { Keefektifan }\end{array}$ & \multicolumn{1}{c}{ Kategori } & \multicolumn{1}{c}{ Keterangan } \\
\hline $81 \%-100 \%$ & Sangat Valid & Sangat tuntas, digunakan, tanpa perbaikan \\
$61 \%-80 \%$ & Cukup Valid & Cukup efektif, digunakan, perlu perbaikan kecil \\
$41 \%-60 \%$ & Kurang Valid & Kurang efektif, Perlu perbaikan besar, disarankan tidak digunakan \\
$21 \%-40 \%$ & Tidak Valid & Tidak efektif, tidak tuntas, tidak bisa dipergunakan. \\
$00 \%-20 \%$ & Sangat Tidak Valid & Sangat tidak efektif, sangat tidak tuntas, tidak bisa dipergunakan. \\
\hline
\end{tabular}

(Sumber: Akbar, 2015:82)

Teknik analisis data deskriptif berupa persentase yang digunakan adalah untuk mempersentase data analisis kebutuhan, data pada uji coba kelompok kecil, dan uji coba kelompok besar. Khususnya pada uji ahli dan uji kelompok teknik analisis persentase digunakan untuk mengetahui kelayakan dan keefektifitasan prototipe produk yang kemudian dapat dikembangkan lagi menjadi lebih baik pada nantinya.

\section{HASIL}

Data hasil analisis kebutuhan yang dilakukan oleh peneliti yaitu, observasi dan pengisian angket terhadap 30 peserta dan 3 pelatih kegiatan ekstrakurikuler renang di SMP 8 Malang. Berikut hasil keseluruhan analisis kebutuhan sebagai langkah (tahapan) awal dalam kegiatan penelitian 
dan pengembangan yang dijelaskan pada tabel 2.

Tabel 2 Data Analisis Kebutuhan

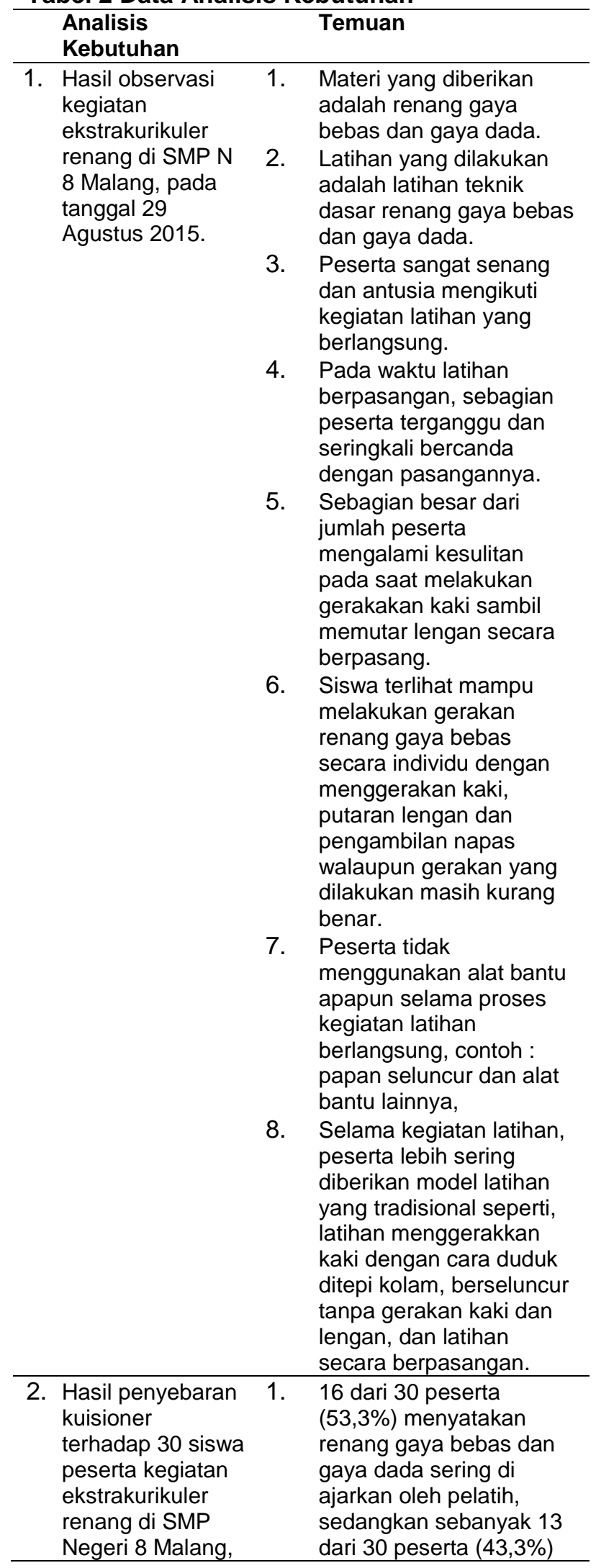

\begin{tabular}{|c|c|c|}
\hline $\begin{array}{l}\text { Analisis } \\
\text { Kebutuhan }\end{array}$ & & Temuan \\
\hline $\begin{array}{l}\text { pada tanggal } 3 \\
\text { Oktober } 2015 .\end{array}$ & 3. & $\begin{array}{l}\text { menyatakan renang gaya } \\
\text { bebas dan gaya dada } \\
\text { pernah di ajarkan oleh } \\
\text { pelatih, } \\
12 \text { dari } 30 \text { peserta (40\%) } \\
\text { menyatakan jarang } \\
\text { mendapatkan variasi } \\
\text { latihan teknik dasar } \\
\text { renang gaya bebas dan } \\
\text { gaya dada yang } \\
\text { bermacam macam, } \\
\text { sedangkan } 11 \text { peserta } \\
\text { dari } 30 \text { ( } 36,6 \%) \\
\text { menyatakan pernah } \\
\text { mendapat variasi latihan } \\
\text { teknik dasar renang gaya } \\
\text { bebas dan gaya dada, } \\
\text { seperti latihan secara } \\
\text { berpasangan dan duduk } \\
\text { sambil menggerakkan } \\
\text { kaki, } \\
25 \text { dari } 30 \text { peserta } \\
\text { (83,33\%) menyatakan } \\
\text { variasi latihan teknik } \\
\text { dasar renang gaya bebas } \\
\text { dan dada sangat } \\
\text { diperlukan untuk } \\
\text { memudahkan dalam } \\
\text { belajar berenang, } \\
30 \text { peserta (100\%) } \\
\text { menyatakan pelatih tidak } \\
\text { pernah menyampaikan } \\
\text { sebuah materi renang } \\
\text { melalui VCD (Video } \\
\text { Compact Disk). }\end{array}$ \\
\hline
\end{tabular}

3. Hasil penyebaran 1. 2 dari 3 narasumber kuisioner terhadap 1 pelatih ekstrakurikuler dan 2 guru (mantan pelatih ekstrakurikuler renang) SMP Negeri 8 Malang menyatakan jarang memberikan model variasi latihan renang gaya bebas dan dada yang bermacam macam, sedangkan 1 narasumber menyatakan pernah memberikan model variasi latihan renang gaya bebas dan dada yang bermacam macam, seperti latihan secara berpasangan dan duduk sambil menggerakkan kaki,

2. 3 narasumber menyatakan tidak pernah memberikan materi variasi latihan renang gaya bebas dan gaya dada melalui video,

3. 3 narasumber menyatakan variasi latihan teknik dasar renang gaya bebas dan dada sangat diperlukan 
Mohammad Syamsul Anam, Pengembangkan Variasi Latihan Teknik Dasar Renang Gaya Bebas Dan Gaya Dada Melalui Video Compact Disk Pada Kegiatan Ekstrakurikuler Renang Di SMP Negeri 8 Malang

\begin{tabular}{ll}
\hline $\begin{array}{l}\text { Analisis } \\
\text { Kebutuhan }\end{array}$ & Temuan \\
\hline & $\begin{array}{l}\text { untuk memudahkan } \\
\text { dalam belajar berenang. }\end{array}$ \\
\hline
\end{tabular}

Berdasarkan hasil analisis kebutuhan dapat disimpulkan, kegiatan ekstrakurikuler renang di SMP Negeri 8 Malang selalu mengajarkan materi renang gaya bebas dan gaya dada, kegiatan selalu di awali dengan latihan teknik dasar renang gaya bebas dan gaya dada, peserta sangat antusias mengikuti jalannya kegiatan ekstrakurikuler, pelatih jarang memberikan model latihan yang bermacam macam selama kegiatan ekstrakurikuler dan lebih sering memberikan model latihan yang tradisional, seperti latihan menggerakkan kaki dengan cara duduk ditepi kolam, berseluncur tanpa gerakan kaki dan lengan, dan latihan secara berpasangan, selama kegiatan latihan berlangsung peserta melakukan aktivitas latihan tanpa menggunakan alat bantu apapun misal papan seluncur dan alat bantu lainnya, sebagian peserta juga belum pernah mendapatkan materi latihan renang gaya bebas dan gaya dada melalui video compact disk atau berupa video.

\section{Tahap Uji Coba}

\section{Hasil Evaluasi Ahli Praktisi (Pelatih Cabang Olahraga Renang)}

Berikut hasil evaluasi dari ahli praktisi kepelatihan olahraga renang yaitu Bapak Ir. Josef Handoko selaku pelatih renang nasional A dan pemilik Perkumpulan Renang Catalina kota Malang terhadap rancangan produk pengembangan variasi latihan teknik dasar renang gaya bebas dan gaya dada melalui video compact disk pada kegiatan ekstrakurikuler renang di SMP Negeri 8 Malang. Tabel tersebut menyajikan 5 indikator dari 21 variasi latihan dengan jumlah total 106 pertanyaan.

Tabel 3. Hasil Evaluasi Ahli Praktisi Kepelatihan Olahraga Renang

\begin{tabular}{lllll}
\hline Aspek & Tse & TSh & $\mathbf{( \% )}$ & Keterangan \\
\hline Kemenarikan & 63 & 84 & 75 & Cukup Valid \\
Pemahaman & 63 & 84 & 75 & Cukup Valid \\
Kemudahan & 84 & 84 & 100 & Sangat Valid \\
Kesesuaian & 66 & 88 & 75 & Cukup Valid \\
Manfaat & 84 & 84 & 100 & Sangat Valid \\
\hline Total & $\mathbf{3 6 0}$ & $\mathbf{4 2 4}$ & $\mathbf{8 4 , 9}$ & Sangat Valid \\
\hline
\end{tabular}

Berdasarkan tabel data hasil evaluasi ahli praktisi kepelatihan olahraga renang, dapat disimpulkan bahwa produk yang dikembangkan oleh peneliti sangat valid dan layak untuk di uji cobakan pada kelompok kecil dan besar, dengan beberapa saran yaitu; (1) Kurangnya penjelasan pada latihan Arm practices di atas mejadengan tali karet mengenai pull-push-recovery, (2) Jangan mengulang kata-kata latihan dan practices pada bagian kalimat penjelasan tiap variasi, (3) terjadi kesalahan pada penjelasan latihan meluncur berpasangan seharusnya pengambilan napas lewat mulut dan di keluarkan melalui hidung, (4) ubah nama variasi latihan Gliding pairs dengan nama yang mudah di pahami, (5) Variasi-variasi tersebut dapat digunakan selama tidak mengganggu prinsip gerakan renang yang ada, bagaimanapun gerakan renang merupakan kordinasi gerakan sebuah tubuh. Termasuk di antarannya kelenturan, keseimbangan, daya apung yang berbeda pada masing-masing individu, (6) variasi-variasi tersebut dapat digunakan sebagai alat bantu untuk melakukan gerakan gerakan prinsip dengan baik (bisa dilihat diproduk DVD/print out produk).

\section{Hasil Evaluasi Ahli Akademisi (Dosen pengampu mata kuliah Kepe-latihan Cabang Olahraga Renang)}

Berikut hasil evaluasi dari ahli akademisi kepelatihan olahraga renang yaitu Ibu Dra. Sulistyorini, M.Pd. selaku dosen Jurusan Pendidikan Kepelatihan Olahraga FIK UM terhadap rancangan produk pengembangan variasi latihan teknik dasar renang gaya bebas dan gaya dada melalui video compact disk pada kegiatan ekstrakurikuler renang di SMP Negeri 8 Malang. Tabel tersebut menyajikan 5 indikator dari 21 variasi latihan dengan jumlah total 106 pertanyaan.

Tabel 4. Hasil Evaluasi Ahli Akademisi Kepelatihan Olahraga Renang

\begin{tabular}{lllll}
\hline Aspek & Tse & Tsh & (\%) & Keterangan \\
\hline Kemenarikan & 80 & 84 & 95 & Sangat Valid \\
Pemahaman & 70 & 84 & 83 & Sangat Valid \\
Kemudahan & 64 & 84 & 76 & Cukup Valid \\
Kesesuaian & 81 & 88 & 92 & Sangat Valid \\
Manfaat & 77 & 84 & 91 & Sangat Valid \\
\hline Total & $\mathbf{3 7 2}$ & $\mathbf{4 2 4}$ & $\mathbf{8 7}$ & Sangat Valid \\
\hline
\end{tabular}

Berdasarkan table data hasil evaluasi ahli akademisi kepelatihan olahraga renang, dapat disimpulkan bahwa produk yang dikembangkan oleh peneliti sangat valid dan layak untuk di uji cobakan pada kelompok 
kecil dan besar, dengan beberapa saran yaitu; (1) Variasi Latihan gaya bebas dan gaya dada yang vertical sangat sulit dilakukan (Latihan tersebut dihapus), (2) Latihan meluncur berpasangan sebaiknya pada waktu pengambilan napas dilakukan dengan menyamping, (3) Gerakan kaki gaya dada harus ada gerak meluncur (kaki rapat), (4) Kegiatan estafet masing - masing anak harus membawa papan pelampung/seluncur (bisa dilihat diproduk DVD/print out produk).

\section{Ahli Media (Dosen Pengampu Mata Kuliah Teknologi Pembelajaran)}

Berikut hasil evaluasi dari ahli media yaitu Bapak Eka Pranomo Adi, S.I.P, M.Si selaku dosen Fakultas IImu Pendidikan FIP UM terhadap rancangan produk pengembangan variasi latihan teknik dasar renang gaya bebas dan gaya dada melalui video compact disk pada kegiatan ekstrakurikuler renang di SMP Negeri 8 Malang. Tabel tersebut menyajikan 5 indikator dari 21 variasi latihan dan tampilan awal video dengan jumlah total 110 pertanyaan.

Tabel 5. Hasil Evaluasi Ahli Media.

\begin{tabular}{|c|c|c|c|c|}
\hline Aspek & TSe & TSh & $(\%)$ & Ket \\
\hline Kemenarikan & 69 & 92 & 75 & Cukup Valid \\
\hline $\begin{array}{l}\text { Kejelasan } \\
\text { Caption }\end{array}$ & 69 & 92 & 75 & Cukup Valid \\
\hline Kejelasan Video & 63 & 84 & 75 & Cukup Valid \\
\hline Mudah Dipahami & 63 & 84 & 75 & Cukup Valid \\
\hline Manfaat & 84 & 84 & 100 & Sangat Valid \\
\hline Total & 348 & 436 & 79,8 & $\begin{array}{l}\text { Cukup } \\
\text { Valid }\end{array}$ \\
\hline
\end{tabular}

Berdasarkan data analisis dari tabel tersebut diketahui hasil persentase evaluasi ahli media, dapat disimpulkan bahwa produk yang dikembagkan oleh peneliti cukup valid dan memerlukan perbaikan kecil agar memenuhi syarat kelayakan untuk di uji cobakan pada kelompok kecil dan besar, dengan beberapa saran yaitu; (1) Durasi tayangan video terlalu panjang, (2) Serta bagian teks diatur optimal agar tidak terlalau banyak tayangan barisan teks dalam satu frame/slide (bisa dilihat diproduk DVD/print out produk).

\section{Hasil Uji Coba Kelompok Kecil}

Berikut data yang diperoleh dari uji coba kelompok kecil yang dilakukan mulai pada tanggal 5 Maret sampai 14 Maret 2016 menggunakan subjek 10 peserta. Dengan agenda 4 kali pertemuan dan setiap pertemuan setelah mempraktikkan variasi latihan, peserta mengisi instrumen penelitian berupa angket, variabel kelayakan isi dengan indikator kemenarikan, pemahaman, kemudahan, dan manfaat yang terdiri dari 4 indikator tiap pertanyaan dengan jumlah total 77 pertanyaan berikut tersaji pada table berikut:

Tabel 6 Data Hasil Uji Coba Kelompok Kecil

\begin{tabular}{ccccc}
\hline \multicolumn{1}{c}{ Aspek } & TSe & TSh & $\mathbf{( \% )}$ & Keterangan \\
\hline Kemenarikan & 647 & 760 & 85,13 & Sangat Valid \\
Pemahaman & 643 & 760 & 84,6 & Sangat Valid \\
Kemudahan & 648 & 760 & 85,26 & Sangat Valid \\
Manfaat & 682 & 800 & 85,25 & Sangat Valid \\
\hline \multicolumn{1}{c}{ Total } & $\mathbf{2 6 2 0}$ & $\mathbf{3 0 8 0}$ & $\mathbf{8 5 , 0 6}$ & Sangat Valid \\
\hline
\end{tabular}

Berdasarkan table hasil uji coba kelompok kecil pada peserta kegiatan ekstrakurikuler renang di SMP Negeri 8 Malang diperoleh hasil $85,06 \%$ artinya sangat valid tanpa adanya revisi (perbaikan). Sehingga variasi latihan teknik dasar renang gaya bebas dan gaya dada melalui video compact disk pada kegiatan ekstrakurikuler renang di SMP Negeri 8 Malang ini menarik, mudah dipahami, mudah dilakukan dan bermanfaat, serta layak untuk diuji cobakan pada kelompok besar. Bedasarkan catatan lapangan di temukan 1) kurangnya sarana pendukung seperti meja atau bangku di area kolam, sehingga variasai latihan yang seharusnya dilakukan di atas meja dialihkan di tangga area kolam, 2) 2 peserta kurang mampu mempraktikkan variasi latihan 1.1.f meluncur dengan posisi miring secara estafet, 3) beberapa peserta asik mengobrol atau susah dikondisikan.

\section{Hasil Uji Coba Kelompok Besar}

Berikut data yang dilakukan berdasarkan data hasil uji coba kelompok besar yang dilakukan mulai pada tanggal 19 Maret sampai 28 Maret 2016 menggunakan subjek 30 peserta. Dengan agenda 4 kali pertemuan dan setiap pertemuan setelah mempraktikkan variasi latihan, peserta mengisi instrumen penelitian berupa angket, variabel kelayakan isi dengan indikator kemenarikan, pemahaman, kemudahan, dan manfaat yang terdiri dari 4 indikator tiap pertanyaan dengan jumlah total 77 pertanyaan berikut tersaji pada table berikut: 
Mohammad Syamsul Anam, Pengembangkan Variasi Latihan Teknik Dasar Renang Gaya Bebas Dan Gaya Dada Melalui Video Compact Disk Pada Kegiatan Ekstrakurikuler Renang Di SMP Negeri 8 Malang

Tabel 7 Data Hasil Uji Coba Kelompok Besar

\begin{tabular}{crrrr}
\hline \multicolumn{1}{c}{ Aspek } & TSe & TSh & $\mathbf{( \% )}$ & Ket \\
\hline Kemenarikan & 2057 & 2280 & 90,2 & Sangat Valid \\
Pemahaman & 2032 & 2280 & 89,1 & Sangat Valid \\
Kemudahan & 2071 & 2280 & 90,8 & Sangat Valid \\
Manfaat & 2227 & 2400 & 92,7 & Sangat Valid \\
\hline Total & $\mathbf{8 3 8 7}$ & $\mathbf{9 2 4 0}$ & $\mathbf{9 0 , 7}$ & Sangat Valid \\
\hline
\end{tabular}

Berdasarkan tabel 4.11 data hasil uji coba kelompok besar pada peserta kegiatan ekstrakurikuler renang di SMP Negeri 8 Malang diperoleh hasil 90,76\% artinya sangat valid tanpa adanya revisi (perbaikan). Sehingga variasi latihan teknik dasar renang gaya bebas dan gaya dada melalui video compact disk pada kegiatan ekstrakurikuler renang di SMP Negeri 8 Malang ini menarik, mudah dipahami, mudah dilakukan dan bermanfaat untuk bahan refrensi sumber belajar bagi latihan dalam memberikan materi latihan dan bagi peserta dalam belajar renang gaya bebas dan gaya dada.

\section{PEMBAHASAN}

Kegiatan ekstrakurikuler renang merupakan kegiatan tambahan yang dilakukan diluar kegiatan belajar mengajar intrakurikuler sebagai perluasan dalam hal mengembangkan potensi, bakat minat anak dalam ketrampilan olahraga renang. Menurut Mulyono (2008:187) ekstrakurikuler adalah kegiatan pelajaran yang diselenggarakan di luar jam pelajaran biasa yang dimaksudkan mengembangkan salah satu bidang pelajaran yang diminati oleh sekelompok siswa misalnya olahraga, kesenian, dan berbagai kegiatan keterampilan dan kepramukaan.

Kegiatan ekstrakurikuler renang di SMP Negeri Malang dilakukan setiap 2 kali seminggu, dan output dari kegiatan tersebut untuk memberikan pelatihan guna meningkatkan ketrampilan renang para peserta, bahkan juga menciptakan bibit - bibit atlet renang. Pada dasarnya proses latihan untuk mencapai tujuan tersebut membutuhkan waktu yang panjang dan lama. Menurut Bompa (dalam Budiwanto, 2012:12) mengemukakan bahwa latihan merupakan suatu kegiatan olahraga yang sistematis dalam waktu yang panjang, ditingkatkan secara bertahap dan perorangan, bertujuan membentuk manusia yang berfungsi fisiologis dan psikologisnya untuk memenuhi tugas. Proses kegiatan yang panjang dan lama pada kenyataanya akan menimbulkan rasa jenuh dan kebosanan terhadap para peserta kegiatan. Menurut Hazeldine (dalam Budiwanto, 2012:17) menjelaskan bahwa latihan membutuhkan waktu yang lama untuk memperoleh adaptasi fisiologis yang bermanfaat, sehingga ada ancaman terjadi kebosanan dan monoton.

Mengatasi hal tersebut dibutuhkan kemampuan dari pelatih untuk membuat program latihan yang bermacam - macam dalam suatu kegiatan latihan. Menurut Budiwanto (2012:18) Dalam upaya mengatasi kebosanan dan latihan yang monoton, diharapkan seorang pelatih kreatif dengan memiliki banyak pengetahuan dan berbagai jenis latihan yang memungkinkan dapat berganti-ganti secara periodik. Tetapi hal tersebut yang menjadi masalah utama di kegiatan ekstrakurikuler renang di SMP Negeri 8 Malang, Selama kegiatan latihan peserta hanya diberikan model latihan yang tradisional, seperti latihan menggerakkan kaki dengan cara duduk ditepi kolam, berseluncur tanpa gerakan kaki dan lengan, dan latihan secara berpasangan. Hal tersebut, peneliti melakukan penelitian dan pengembangan variasi latihan teknik dasar renang gaya bebas dan gaya dada, sebagai upaya pemecahan masalah pada kegiatan ekstrakurikuler renang di SMP Negeri 8 Malang.

Proses penelitian ini diawali dengan analisis kebutuhan yaitu observasi dan penyebaran koesioner, dilanjutkan pengembangan produk yang di evaluasi oleh 3 ahli yaitu praktisi kepelatihan renang, akademisi kepelatihan renang dan ahli media. Berdasarkan hasil evaluasi ahli peneliti melakukan perbaikan mengenai produk yang di kembangkan sesuai dengan saran dari ahli guna untuk meningkatkan keefektifitasaan prodak. Selanjutnya dilakukan uji coba kelompok kecil dan kelompok besar serta perbaikan hasil dari uji kelompok tersebut sehingga produk akhir sudah disesuaikan dengan kebutuhan yang ada. Langkah langkah tersebut harus dilakukan secara bertahap dan berurutan agar tercipta sebuah produk penelitian dan pengambangan yang baik dan hasil penelitian dapat digunakan.

Produk pengembangan variasi latihan teknik dasar renang gaya bebas dan gaya dada melalui video compact disk pada kegiatan ekstrakurikuler renang di SMP Negeri 8 Malang ini adalah sebuah produk 
yang dilandasi berdasarkan analisis kebutuhan dan teori. Kemudian disusun produk pengembangan ini untuk menjawab kebutuhuan tersebut. Dalam pembuatan produk ini, dibutuhkan proses yang panjang. Hal tersebut memungkinkan terjadi kesalahan atau kekurangan pada hasil produk yang dikembangkan nantinya. Produk ini diselesaikan melalui beberapa tahapan yang berkelanjutan, mulai dari rancangan produk awal sampai hasil produk akhir.

Pada tahapan pembuatan produk awal, berupa variasi latihan teknik dasar renang gaya bebas dan gaya dada yang dikemas dalam bentuk VCD, terdiri dari 21 variasi latihan, yang dilakukan di darat dan di air dengan tambahan permainan estafet. Variasi latihan tersebut juga menggunakan alat bantu seperti papan seluncur, tali karet dan papan kertas berpola hati. Tahapan selanjutnya melalui evaluasi dari ahli praktisi kepelatihan olahraga renang, ahli akademisi kepelatihan olahraga renang dan ahli media. Setelah melalui tahapan evaluasi, maka selanjutnya peneliti melakukan revisi produk. Setelah melakukan evaluasi dan revisi produk, peneliti melakukan tahapan selanjutnya yaitu uji kelompok kecil sekaligus dilanjutkan dengan tahapan akhir yaitu uji kelompok besar pada peserta ekstrakurikuler renang di SMP Negeri 8 Malang.

Melalui beberapa tahapan tersebut, maka dihasilkan sebuah produk berupa variasi latihan teknik dasar renang gaya bebas dan gaya dada yang dikemas dalam bentuk VCD, yang terdiri dari 19 variasi latihan beserta tata pelaksanaan yang nantinya akan digunakan pada kegiatan ekstrakurikuler renang di SMP Negeri 8 Malang.

Produk akhir dari pengembangan variasi latihan teknik dasar renang gaya bebas dan gaya dada ini dikemas dalam bentuk VCD (Video Compact Disc), isi produk meliputi; (1) Variasi latihan teknik dasar renang gaya bebas dan gaya dada, (2) Variasi latihan renang gaya bebas didarat yaitu: 1.1.a Leg practices dengan posisi berbaring di atas lantai, 1.1.b Leg practices dengan kaki menggantung di atas meja, 1.1.c Arm practices di atas meja, 1.1.d Arm practices di atas mejadengan tali karet. Di air yaitu: 1.2.a Leg practices menggunakan tali karet, 1.2.b Estafetleg practices menggunakan tali karet, 1.2.c Estafetleg practices dengan tali karet sambil menundukkan kepala, 1.2.d Meluncur berpasangan, 1.2.e Latihan gerakan lengan dan pengambilan napas secara berpasangan, 1.2.f Latihan meluncur dengan posisi badan miring secara estafet, 1.2.g Crawl practices (latihan keseluruhan). (3) variasi latihan renang gaya dada di darat yaitu: 2.1.a Leg practices dengan berbaring di lantai, 2.1.b Leg practices dengan kaki menggantung, 2.1.c Arm practices dengan mengikuti pola gambar, 2.1.d Arm practices dengan tali karet. Di air yaitu: 2.2.a Estafet leg practices, 2.2.b : Estafet leg practices sambil menundukkan kepala, 2.2.c Arm practices (berpasangan), 2.2.d Estafet breaststroke practices (latihan keseluruhan). (4) Hasil akhir pengembangan variasi latihan teknik dasar renang ini dikemas dalam bentuk VCD (Video Compact Disk) dan disertai caption (teks tertulis) sesuai dengan gerakan variasi latihan pada video.

\section{KESIMPULAN}

Berdasarkan hasil penelitian dan pengembangan terhadap pengembangan variasi latihan teknik dasar renang gaya bebas dan gaya dada yang telah dilakukan melalui beberapa tahap dari evaluasi ahli, uji kelompok kecil serta uji kelompok besar, dapat disimpulkan: (1) Variasi latihan teknik dasar renang gaya bebas dan gaya dada sangat valid artinya dapat digunakan, (2) Variasi latihan teknik dasar renang gaya bebas dan gaya dada sngat valid artinya dapat digunakan, (3) Variasi latihan teknik dasar renang gaya bebas dan gaya dada yang dikembangkan sangat menarik, mudah dipahami, mudah dilakukan, bermanfaat untuk digunakan pada kegiatan ekstrakurikuler renang.

\section{SARAN}

Sehubungan dengan produk yang telah dikembangkan yaitu pengembangan variasi latihan teknik dasar renang gaya bebas dan gaya dada melalui video compact disk. Saran saran yang dikemukakan sebagai berikut.

Saran pemanfaatan, diharapkan dapat meningkatkan minat dan ketertarikana 
Mohammad Syamsul Anam, Pengembangkan Variasi Latihan Teknik Dasar Renang Gaya Bebas Dan Gaya Dada Melalui Video Compact Disk Pada Kegiatan Ekstrakurikuler Renang Di SMP Negeri 8 Malang

peserta dalam berlatih renang gaya bebas dan gaya dada, dan sekaligus sebagai referensi sumber belajar bagi pelatih dalam memberikan materi latihan. Sebaiknya pelatih dalam menggunakan produk ini memilih dan menentukan latihan yang akan diberikan. Sebagai saran hendaknya variasi latihan yang akan diberikan dari tingkatan yang paling mudah ke tingkatan yang paling sulit, sehingga peserta tidak merasa kesulitan dalam mempraktikkannya.

Sebagai upaya untuk penyebarluasan produk yang telah dikembangkan kesasaran yang lebih luas lagi, saran dari peneliti adalah sebagai berikut:

a. Sebelum disebarluaskan, sebaiknya produk ini dikaji ulang sesuai dengan kebutuhan, situasi dan keadaan yang ada. Sehingga pengembangan variasi latihan teknik dasar renang gaya bebas dan gaya dada ini, lebih menarik dan bermanfaat nantinya.

b. Sebaiknya dilakukan penelitian lebih lanjut untuk mengetahui tingkat efektivitas dari produk yang dikembangkan ini, karena hasil dari pengembangan ini terbatas sampai tersusunnya sebuah produk saja.

c. Sebelum disebarluaskan, sebaiknya produk yang telah dikembangkan ini disosialisasikan kepada pihak-pihak yang terkait.

\section{DAFTAR RUJUKAN}

Ardhana, W. 2002. Konsep Penelitian Pengembangan dalam Bidang Pendidikan dan Pembelajaran. Malang: Universitas Negeri Malang.

Akbar, Sa'dun. 2015. Instrumen Perangkat Pembelajaran. Bandung: PT Remaja Rosdakarya.

Badan Penelitian dan Pengembangan. 2013. Kompetensi Dasar SMP/MTs Kurikulum 2013. Kementrian Pendidikan dan kebudayaan.

Peraturan Kementrian Pendidikan Dan Kebudayaan (Permendikbud). 2013. Pembinaan Kesiswaan. Kementrian Pendidikan Dan Kebudayaan.
Borg, Walter \& M.D. Gall. 1979. Educational Research An Introduction. New York: Logman.

Budiwanto, Setyo. 2012. Metodologi Latihan Dan Olahraga. Malang: Jurusan IImu Keolahragaan FIP UM Universitas Negeri Malang.

Dwiyogo D, Wasis. 2010. Dimensi Teknologi Pembelajaran Pendidikan Jasmani \& Olahraga. Malang: Wineka Media.

Hadisasminta, M., Yusuf \& Syarifuddin, Aip. 1996. IImu Kepelatihan Dasar. Jakarta: Departemen Pendidikan dan kebudayaan, Direktorat Jendral Pendidikan Tinggi.

Haller, David. 2007. Belajar Berenang. Bandung: Pioner Jaya.

Harsono. 1988. Coaching Dan Aspek-Aspek Psikologis Dalam Coaching. Jakarta: Departemen Pendidikan dan Kebudayaan, Direktorat Jendral Pendidikan Tinggi, Proyek Pengembangan Lembaga Pendidikan Tenaga Kependidikan.

Kompri. 2014. Manajemen Pendidikan Komponen-komponen Elementer kemajuan Sekolah. Yogyakarta: ArRuzz Media.

Lekso, Faradise, M. 2013. Pengaruh Metode Latihan Dan Power Tungkai Terhadap Kecepatan Berenang 50 Meter Gaya Dada Pada Atlet Kelompok Umur IV Perkumpulan Renang Spectrum Semarang. Unnes Journal of Sport Sciences, (Online), U-JSS 2 (1): 1:14, (http://journal. unnes.ac.id/sju/index.php/ujss), diakses 22 Oktober 2015.

Mereditha, Susan. 2006. Mengajar Anak Berenang. Gapprint Erlangga.

Miarso, Yusufhadi. 2007. Menyemai Benih Teknologi Pendidikan. Jakarta: Kencana. 
Mulyono, M A. 2008.Managemen Administrasi \& Olahraga Pendidikan. Jogjakarta: Ar-Ruzz Media.

Nawangsari, Dewi. 2009. Dasar-Dasar Berenang. Klaten: PT. Macanan Jaya Cemerlang.

Roeswan dan Soekarno. 1979. Renang dan Methodik. Jakarta: PT. Karya Unipress.

Sidik, Zafar. D. 2010. Prinsip Prinsip Latihan Dalam Olahraga Prestasi. (Online), (https://penjasorkessman3.files.word press.com/2010/08/1-prinsip-prinsiplatihan-oleh-dikdik-zafar-sidik.pdf), diakses pada tanggal 30 Oktober 2015.

Sugiyono. 2011. Metode Penelitian Kuantitatif Kualitatif dan $R \& D$. Bandung: Alfabet.

Supriyanto, A., Lismadiana. 2013. Penggunaan Metode Hypnoterapi Untuk Meningkatkan Konsentrasi Saat Start Dalam Renang. Jurnal IPTEK Olahraga, 15 (2): 111-124.

Tim Universitas Negeri Malang. 2010. Pedoman Penulisan Karya IImiah: Skripsi, Tesis, Disertasi, Artikel, Makalah, Tugas Akhir, Laporan Penelitian (Edisi Kelima). Malang: Universitas Negeri Malang.

Winarno, M.E. 2011. Metodologi Penelitian dalam Pendidikan Jasmani. Malang: Universitas Negeri Malang. 